\title{
Evaluation of Deterioration of Larix kaempferi Wood Heat-treated by Superheated Steam through Field Decay Test for 12 Months ${ }^{1}$ (알
}

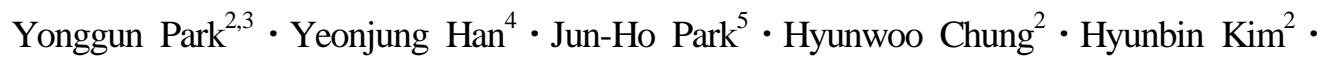 \\ Sang-Yun Yang $^{2} \cdot$ Yoon-Seong Chang ${ }^{4} \cdot$ Hwanmyeong Yeo $\mathbb{D}^{2,3, \dagger}$
}

\begin{abstract}
In this study, the decay resistance of larch wood, which was heat treated by superheated steam, was evaluated by the field decay test. During the field decay test of 12 months, non-treated wood has been severely damaged by termite, however, no visible damage has occurred in the preservative-treated wood and superheated steam heat-treated wood. Results of field decay test showed approximately 5\% mass loss of the non-treated wood and the preservative-treated wood, and approximately $1 \%$ mass loss of the superheated steam heat-treated wood. After the field decay test for 12 months, the residual amount of preservatives remaining in the preservative-treated wood was lower than that before the field decay test. It was considered that the preservative was partially eluted during the field decay test, and the mass loss of the preservative-treated wood was thought to be similar to that of the non-treated wood. Through this study and additional long-term monitoring test, superheated steam heat treatment can be considered to be an environmental-friendly method to enhance the decay resistance of wood against rot fungi and/or insect without chemical treatment such as preservative injection.
\end{abstract}

Keywords: field decay test, decay resistance, wood rot fungi, termite, superheated steam heat-treatment

\section{INTRODUCTION}

Heated at a high temperature $\left(160 \sim 260^{\circ} \mathrm{C}\right)$, the principal components that consist of the cell walls of wood (cellulose, hemicellulose, and lignin, etc.) experience chemical changes like thermal hydrolysis process, which results in changing the physical-dynamic as well as weatherproof performance (Militz, 2002; Park et al., 2016). Various research on wood heat treatment as an environmental-friendly preservative and insect-proof

${ }^{1}$ Date Received May 4, 2018, Date Accepted September 7, 2018

${ }^{2}$ Department of Forest Sciences, College of Agriculture \& Life Sciences, Seoul National University, 1 Gwanak-ro, Gwanak-gu, Seoul 08826, Republic of Korea

${ }^{3}$ Research Institute of Agriculture \& Life Sciences, Seoul National University, 1 Gwanak-ro, Gwanak-gu, Seoul 08826, Republic of Korea

${ }^{4}$ Department of Forest Products, National Institute of Forest Science, 57 Hoegi-ro, Dongdaemun-gu, Seoul 02455, Republic of Korea

5 SDI R\&D Center, Samsung SDI Co., LTD., 130 Samsung-ro, Yeongtong-gu, Suwon-si, Gyeonggi-do 16678, Republic of Korea

† Corresponding author: Hwanmyeong Yeo (e-mail: hyeo@snu.ac.kr, ORCID: 0000-0002-1779-069X) 
Yonggun Park • Yeonjung Han · Jun-Ho Park • Hyunwoo Chung $\cdot$ Hyunbin Kim • Sang-Yun Yang • Yoon-Seong Chang $\cdot$ Hwanmyeong Yeo

process since the early 2000s has been conducted mainly in Europe. It has been reported that the color of heat-treated wood turns darker, its dimensional stability improves as the hydrophobic property increases, and its weatherproof performance increases (Repellin and Guyonnet, 2005; Esteves et al., 2008; Yoon et al., 2008; 2009; Park et al., 2012; 2014; 2015; 2016). Thanks to such property changes, heat-treated wood is considered to be widely used for garden furniture, fences, pillars, wood storage closets, window frames, doors, furniture, deck materials, outdoor wall materials and flooring materials where dimensional stability or weatherproof performance is required (Esteves and Fereira, 2009; Kim, 2016). The property changes of wood by heat treatment differ depending on the temperature and duration of heat treatment, as well as the types of heat transfer media used for heat treatment (Kim, 2016). Dimensional stability due to the increase of the hydrophobic property has been recognized by many studies on the property changes of heat-treated wood under various conditions (MIlitz, 2002; Homan et al., 2004; Sandberg et al., 2013; Kim, 2016). It has also been reported that the resistance of heat-treated wood to bio-deteriorating factors increases thanks to the chemical changes of the cell walls of wood caused by heat (Homan and Jorrison, 2004; Kim, 2016). However, the weatherproof performance of heat-treated wood varies depending on the heat treatment process, process conditions, and the type of wood, and therefore, the development of an optimal process for target wood is urgently required, and furthermore, heat treatment needs to be carefully considered based on the environmental conditions and usage as it does not exhibit the same weatherproof performance as preservatives against all rot fungi and shows poor weatherproof properties in an environment where wood makes contact with soil or water, and particularly, its resistance to insects is extremely low (Kim, 2016).

Recently, there has been research on the heat treatment with superheated steam on wood (Park et al., 2012; Park et al., 2014; Park et al., 2016; Han et al., 2017; Park et al., 2017a; 2017b). Superheated steam is a steam of which temperature is over the boiling temperature and is used to dry not only wood, but food or sewage sludge (Kim et al., 2008). The heat treatment with superheated steam on wood offers low energy loss and high energy efficiency as the drying and heat treatment of wood are performed at the same time through a single process (Park et al., 2017a). The heat treatment on wood with superheated steam offers superior heat treatment effects to the existing hot air treatment process under the same temperature and duration as the former promotes the thermal hydrolysis process by steam at high temperature and high pressure (Park et al., 2014; Park et al., 2016). This means that the heat treatment with superheated steam causes considerable property changes to wood, such as the increase in the dimensional stability and bending and compressive strengths due to the increase in hydrophobic properties (Park et al., 2016). Furthermore, it has been reported that the decay lab test on heat-treated wood with superheated steam showed that its resistance to brown and white rot fungi greatly increased (Park et al., 2014; Korea Forest Service, 2016).

In the present study, a field decay test was conducted for 12 months to evaluate the deterioration of heat-treated larch with superheated steam. Particularly, the study aimed to evaluate the treated wood's resistance to brown and white rot fungi as well as various insects including termites.

\section{MATERIALS and METHODS}

\subsection{Heat-treated wood with superheated steam}

In this study, we used larch wood purchased from the Dongbu Wood Distribution Center of the National 

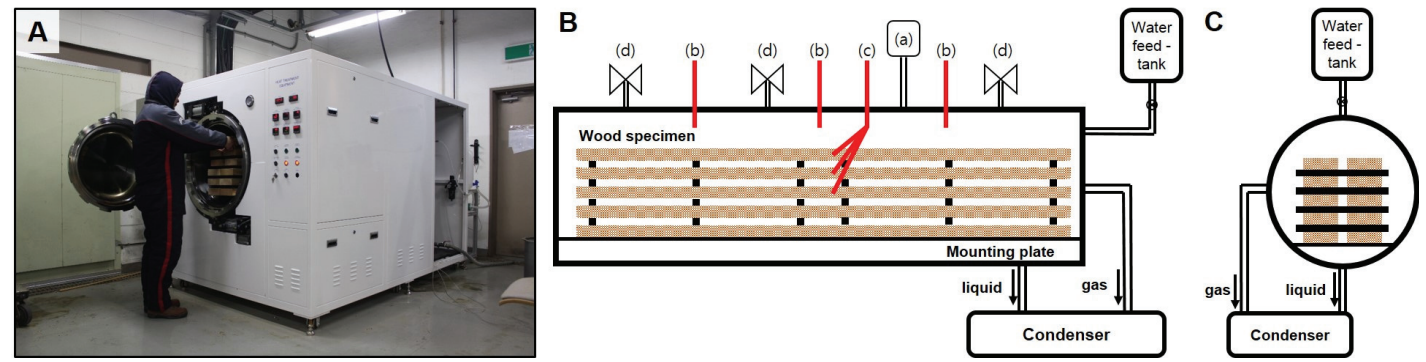

Fig. 1. Wood heat treatment equipment using superheated steam (Park et al., 2016).
A. overall view of the equipment
B. side view of the reactor
(a) pressure sensor
(b) temperature sensors for the steam
(c) temperature sensors for the wood
(d) pressure control valves
C. front view of the reactor

Forestry Cooperatives Federation, which was felled from an area nearby Donghae, Gangwon. The large wood used for the heat treatment was $2.0 \mathrm{~m}(\mathrm{~L}) \times$ $150 \mathrm{~mm}(\mathrm{~W}) \times 50 \mathrm{~mm}(\mathrm{~T})$.

Fig. 1 shows the heat treatment device with superheated steam used in this study (Park et al., 2016). It consists of a reactor, a condenser, a feed tank, and a vacuum pump. The reactor is a cylinder with the internal diameter at $640 \mathrm{~mm}$, its length at $2.2 \mathrm{~m}$, and its internal volume is about $0.7 \mathrm{~m}^{3}$. Using the ceramic heater installed inside the surface of the reactor, the temperature can be increased by up to $400^{\circ} \mathrm{C}$, and there is one pressure sensor which can measure the internal steam pressure, three temperature sensors that can measure the temperature of internal steam, and three temperature sensors that can measure the temperature of the inside of the wood during the heat treatment process. The measured pressure and temperature values can be monitored in real-time by a computer linked to the reactor. The condenser collects and condenses the flammable organic compounds from the wood as well as the moisture vaporized from the wood whereas the feed tank is used to inject distilled water to generate superheated steam when the process starts, and finally the vacuum pump is used to remove internal air when the process starts.

The heat treatment process with superheated steam is as follows. First, larch specimens are piled inside the reactor, and after the reactor is sealed, the distilled water is inserted to generate superheated steam. At this point, the amount of distilled water is determined by the specific volume of superheated steam and the volume of the reactor at the target temperature and pressure conditions. Under the target condition of 0.5 MPa at $250^{\circ} \mathrm{C}$, the specific volume of superheated steam is $0.47 \mathrm{~m}^{3} / \mathrm{kg}$, and the volume of the reactor is 0.7 $\mathrm{m}^{3}$, and thus, the amount of the required moisture to generate superheated steam is about $1.48 \mathrm{~kg}$. However, twice as much as the required amount of distilled water, $3.0 \mathrm{~kg}$, was injected to have the reactor filled with steam fast in the initial stage of the process. After decreasing the internal pressure of the reactor at or below $0.01 \mathrm{MPa}$ by removing internal air with the vacuum pump, the heater is operated to evaporate the distilled water injected to the reactor and increase the internal pressure. Once the internal reactor pressure reaches the target pressure, the target pressure is maintained by taking out the excessive amount of steam 
Yonggun Park • Yeonjung Han · Jun-Ho Park • Hyunwoo Chung $\cdot$ Hyunbin Kim • Sang-Yun Yang • Yoon-Seong Chang $\cdot$ Hwanmyeong Yeo

with the pressure control valve. The internal temperature is maintained at the target temperature with the On/Off system of the heater. The heater is operated for 18 hours.

For the field decay test, we produced 40 specimens from the heat-treated $2.0 \mathrm{~m}$ long larch wood, each of which was $300 \mathrm{~mm}$ in length (fiber direction) and 38 $\mathrm{mm}$ in width and thickness (transversal direction).

\subsection{Non-treated wood and preservative- treated wood}

As a control group, we used non-treated (dried) wood and preservative wood. 40 dried larch stakes and 40 ACQ-II (Alkaline Copper Quaternary) preservativetreated larch stakes of $\mathrm{H} 3$ grade, both of which were $300 \mathrm{~mm}$ in length (fiber direction) and $38 \mathrm{~mm}$ in width and thickness (transversal direction), were purchased from the Dongbu Wood Distribution Center at the National Forestry Cooperatives Federation.

\subsection{Field decay test}

For the field decay test, the estimation testing site at Nambu Experiment Forest, Seoul National University, located at Mt. Baekun, Gwangyang, Jeollanam-do, was selected. The testing site was prepared at a high hill region far from fields and paddles so that chemicals like weed killers or agricultural pesticides cannot be introduced. Referring to AWPA Standard E7-15 ${ }^{『}$ Standard Field Test for Evaluation of Wood Preservatives to be Used in Ground Contact (UC4A, UC4B, UC4C); Stake Test $₫$, the ground was dug up to $150 \mathrm{~mm}$ and all specimens were buried in length so that half of the length of the specimens was put under the ground and the other half was exposed to the air (Fig. 2). The 40 specimens buried on the same day were divided into four groups, each of which was retrieved after three months, six months, nine months, and 12 months, respectively. While AWPA Standard

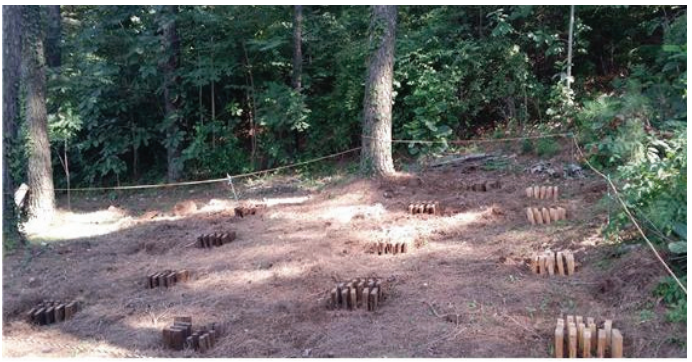

Fig. 2. Field decay test.

stipulates that bare-eyed observation is used to determine the degree of decay of wood, the result of such an evaluation may vary by the evaluator's opinions, and therefore, we aimed to evaluate the change of the weight of specimens after the field decay test by measuring the weight of the specimens before and after the test. Equation (1) was used to evaluate the mass reduction ratio of specimens after the field decay test. At this point, the effect of the moisture content ratio was excluded from the evaluation by measuring the oven-dry weight of the specimens.

Mass loss by field decay test (\%)

$$
=\frac{W_{\text {before }}-W_{\text {after }}}{W_{\text {before }}} \times 100
$$

where $W_{\text {before }}$ is the oven-dry weight (g) before the field decay test, and $W_{\text {after }}$ is the oven-dry weight (g) after the field decay test.

\subsection{Measurement of the remaining preservatives inside the preservative-treated wood}

To evaluate the amount of the remaining preservatives inside the preservative-treated wood, the copper content in the preservative specimens after the field decay test was measured. The preservative wood without the field decay test, the preservative-treated wood after the field 
decay test for three, six, nine and 12 months, and non-treated larch wood without preservatives were pulverized at or below $0.5 \mathrm{~mm}$, and the copper content included in the wood flour by sending the specimens to the Center for the Analysis of Soil Contamination, the National Instrumentation Center for Environmental Management at Seoul National University. The measurement used the ICP (Inductively Coupled Plasma) Mass Spectrometer (Varian 820-MS, Varian, Australia).

Using the copper ion content $(G)$ and the density of the preservative-treated wood $(\rho)$ measured by KS F 2155 (Method of Determination for Preservatives Absorption of Treated Wood), the mass of the copper compound $\left(\mathrm{CuO}, G_{o}\right)$ was calculated, and with the copper compound mass and the volume ( $V$ ) of the preservative-treated wood, the amount of the remaining preservatives ( $R$ ) was determined . (Eq. (2), Eq. (3))

$$
\begin{aligned}
& G_{o}=1.252 \times G \\
& R=\frac{1.786-G_{o}}{V}
\end{aligned}
$$

\section{RESULTS and DISCUSSION}

\subsection{Heat treatment with superheated steam}

Fig. 3 shows the temperature change in wood and the temperature and pressure changes of steam during the heat treatment with superheated steam. Initially, the wood temperature and the steam pressure and temperature soared rapidly. When the steam temperature and pressure reached the target values $\left(250^{\circ} \mathrm{C}\right.$ and 0.5 $\mathrm{MPa}$ ), the internal temperature of wood reached the steam saturation temperature $\left(151.84^{\circ} \mathrm{C}\right)$ at $0.5 \mathrm{MPa}$, which was maintained for about three hours. Park et al. (2014) reported that during the heat treatment with superheated steam, the wood dried up at the point in which the wood temperature increased after it maintained for some time. In other words, while the wood temperature maintained for some time, the internal moisture was completely removed, and the thermal energy that had been used for removing moisture started to be used to raise the wood temperature, resulting in the rise of the temperature. The wood temperature when

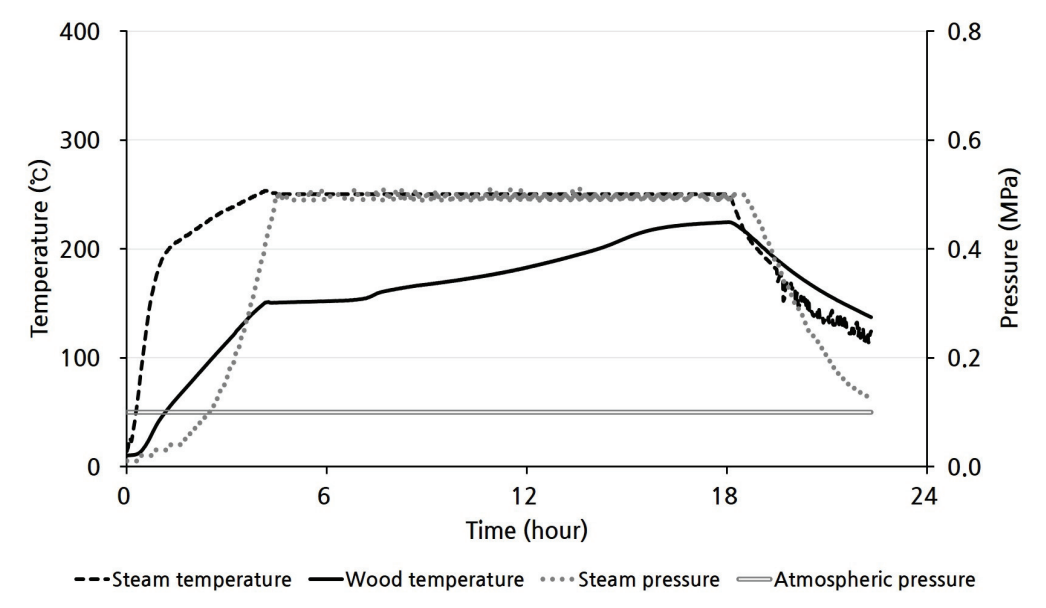

Fig. 3. Changes in steam temperature, wood temperature and steam pressure during the superheated steam heat treatment. 
Yonggun Park • Yeonjung Han · Jun-Ho Park • Hyunwoo Chung • Hyunbin Kim • Sang-Yun Yang • Yoon-Seong Chang $\cdot$ Hwanmyeong Yeo

the process completed was about $220^{\circ} \mathrm{C}$. Considering that it was between 160 and $260^{\circ} \mathrm{C}$ when the chemical changes of the main components of wood occurred due to the heat treatment, it is determined that the wood has been heat-treated for about ten hours.

\subsection{Results of the field decay test}

Fig. 4 shows the mass reduction ratios after the 12-month field decay test. The mass reduction ratio of the non-treated wood changed from $3.70 \% \rightarrow 4.05 \%$ $\rightarrow 4.62 \% \rightarrow 5.19 \%$, showing a $3.7 \%$ mass decrease in the initial three months, and a gradual mass increase as the test continued whereas that of the preservativetreated wood changed from $3.60 \% \rightarrow 5.09 \% \rightarrow 4.80 \%$ $\rightarrow 4.36 \%$, and similar to that of the non-treated wood, it was around $4 \%$, regardless of the duration of the test. On the other hand, the mass reduction ratio of the heat-treated wood with superheated steam changed from $1.10 \% \rightarrow 1.06 \% \rightarrow 0.60 \% \rightarrow 1.06 \%$, which was around $1 \%$ regardless of the duration of the test.

As shown in Fig. 5A, the damage by termite was identified on the non-treated wood after the three-month field decay test while the preservative-treated wood and heat-treated wood with superheated steam did not show any damage by termite (Fig. 5B, C). The result was

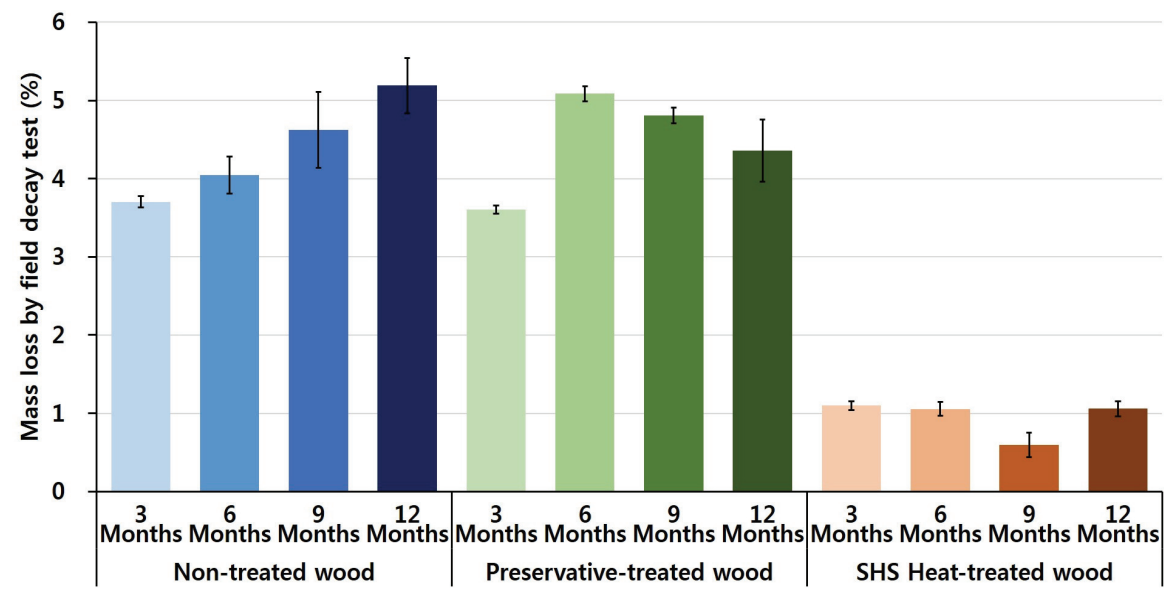

Fig. 4. Mass loss by field decay test.

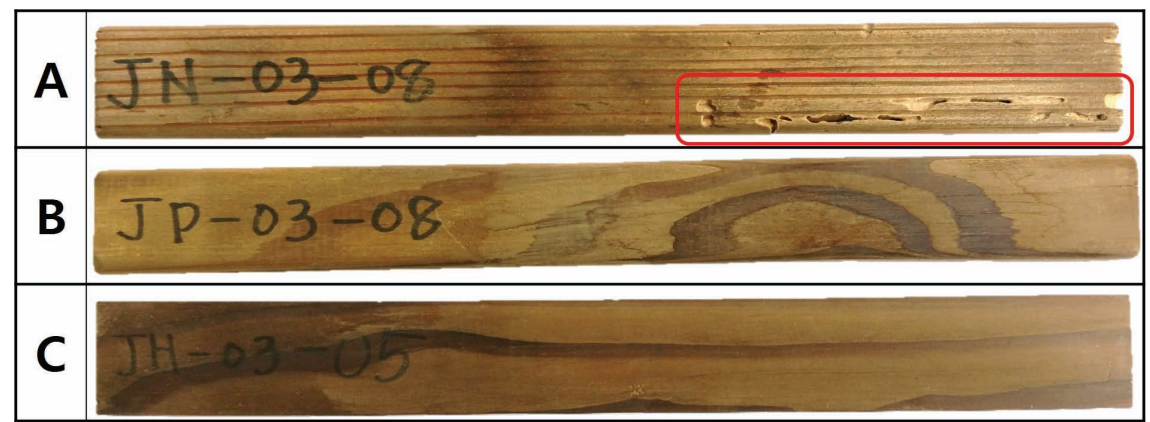

Fig. 5. Non-treated wood (A), preservative-treated wood (B) and heat-treated wood (C) after field decay test during 3 months. 
contrary to previous studies which reported that heat-treated Korean pine (Pinus koraiensis S. et Z.) and lodge-pole pine (Pinus contorta Dougl.) were extremely prone to termite (Ra et al., 2012). The property change of heat-treated wood is believed to be much varied by the type of wood, the treatment temperature and duration, and the thermal media used in the treatment. Ra et al. (2012) performed the heat treatment of Korean pine and lodge-pole pine at 170, 180, 200, 220, and $230^{\circ} \mathrm{C}$ for $90,120,180,240$, and 270 minutes, whereas this study performed the heat treatment on larch with steam at $250^{\circ} \mathrm{C}$ for 18 hours. Since the wood was exposed to steam over $160^{\circ} \mathrm{C}$ for about ten hours, and therefore, the specimens were exposed to the high-temperature longer than in the previous studies. Furthermore, the heat treatment with superheated steam promotes the thermal hydrolysis process by the superheated steam, which is reported to have more heat treatment effects than the existing, hot air-based, process (Park et al., 2016). A considerable amount of hemicellulose, one of the key components of wood, is decomposed, and the decomposed products from hemicellulose are crosslinked with lignin to create high lignin molecules (Esteves et al., 2008; Park et al., 2017b). Such chemical changes lead to the reduction of the number of -OH groups, the increase in the hydrophobicity of wood, and the reduction of the equilibrium moisture content based on the relative humidity. That is, it is determined that the extremely high heat treatment causes the chemical changes and consequently property changes of the wood, and the growth condition of organisms like rot fungi or termite change, and thus, the weatherproof performance of the heat-treated wood with superheated steam improves. However, to determine whether the field decay test on the heat-treated wood with superheated steam was effective, a long-term observation for more than 12 months would be required.

\subsection{Determination for preservatives absorption of treated wood}

The mass reduction ratio of preservative-treated wood in the field decay test was shown to be similar to that of the non-treated wood despite the fact that there was little damage by termite or rot fungi. To evaluate the potential elution of preservatives injected into the wood during the field decay test, the amount of the remaining copper ion, one of the key components of the preservatives, was measured. As shown in Fig. 6, the copper ion content in the preservative-treated wood that was not used in the field decay test was about 4.2 $\mathrm{g} / \mathrm{kg}$ whereas the one used in the field decay test was between 1.5 and $2.5 \mathrm{~g} / \mathrm{kg}$. The unit $(\mathrm{g} / \mathrm{kg})$ used in this measurement means the copper ion content included in $1 \mathrm{~kg}$ of preservative-treated wood. Also shown in Fig. 6 is the remaining preservative content determined by the measured copper ion content $(G)$, the density of the preservative-treated wood $(\rho)$, and the volume of the preservative-treated wood $(V)$. While H4-graded preservative-treated wood should be used for the field decay test that makes contact with the ground, the present test used H3-graded preservative wood. But the preservative content of the preservative-treated wood used in the study was about $4.9 \mathrm{~kg} / \mathrm{m}^{3}$, which was similar to the minimum preservative content of H4-graded wood, and thus, it was determined that the H3-graded preservative-treated wood would be suitable for the test. Although there was no tendency in the amount of the eluted preservative in relation to the duration of the test during the field decay test, the remaining preservative content decreased drastically compared to the preservative-treated wood not used in the test so that it was believed that the preservative was eluted. In other words, the mass reduction of the preservativetreated wood was not only due to the deterioration by rot fungi or weathering, but also by the elution of the preservative injected to the wood. 
Yonggun Park • Yeonjung Han • Jun-Ho Park • Hyunwoo Chung • Hyunbin Kim • Sang-Yun Yang •

Yoon-Seong Chang $\cdot$ Hwanmyeong Yeo

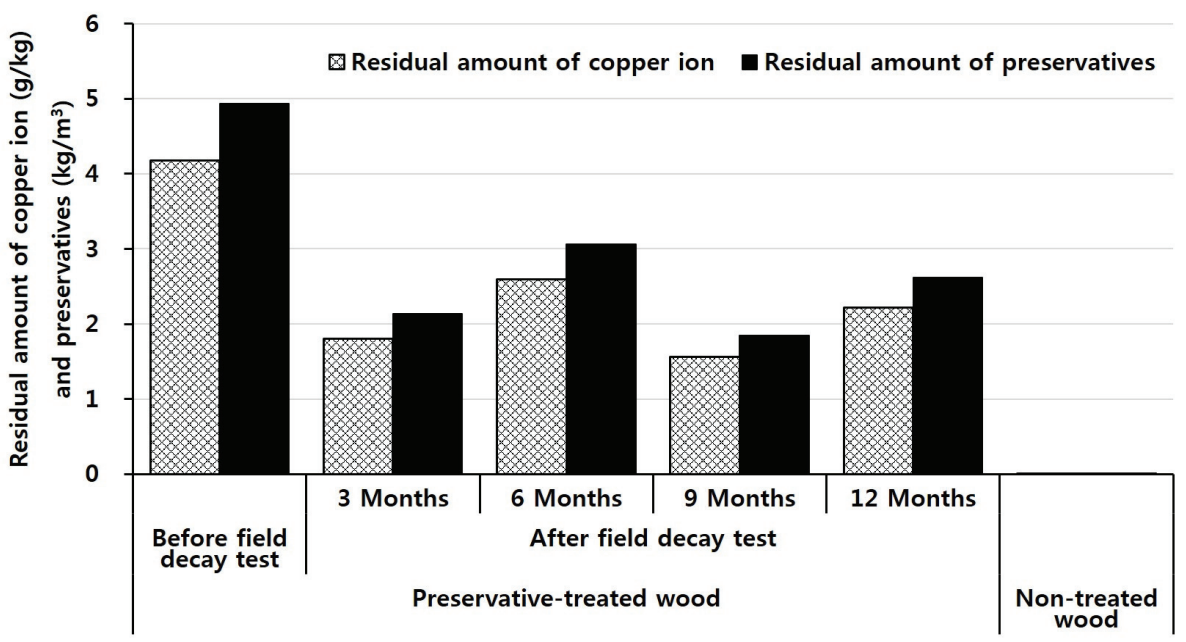

Fig. 6. Residual amount of copper ion and preservatives.

\section{CONCLUSION}

In this study, we evaluated the resistance performance of heat-treated larch wood with superheated steam against rot fungi and insects through the field decay test. The heat treatment process with superheated steam was conducted under the superheated steam conditions of $0.5 \mathrm{MPa}$ at $250^{\circ} \mathrm{C}$ for 18 hours of the heater operation, at which the maximum internal temperature of the wood was $220^{\circ} \mathrm{C}$, and under the temperature at or over $160^{\circ} \mathrm{C}$ when the heat treatment of wood is performed, wood was exposed to the steam for about ten hours. As a control group for the field decay test, the study used the non-treated wood and H3-graded preservative wood injected with ACQ-II preservative (preservative content: $4.9 \mathrm{~kg} / \mathrm{m}^{3}$ ).

The results of the 12-month field decay test showed that the mass reduction of the heat-treated wood with superheated steam was about $1 \%$, and the visual inspection showed no damage by rot fungi or termite. On the other hand, the mass reduction of the non-treated wood was about $5 \%$, and there was marked damage by termite. The mass reduction of the preservative- treated wood was also about $5 \%$, but there was no termite damage. The measurement of the remaining preservative content injected in the preservative-treated wood showed that some of the preservatives were eluted. In other words, the mass reduction of the preservativetreated wood during the field decay test was not only by the rot fungi or weathering, but also by the elution of the preservative.

While the existing studies have reported that the resistance of heat-treated wood to termite was extremely low, the results of the present study after the 12-month field decay test showed that the resistance performance of the heat-treated larch wood with superheated steam against termites was extremely high. It is believed that this is because of the huge heat treatment effect as the wood was exposed at the high temperature for a long time. However, due to the characteristics of the field decay test that requires long-term observation, the results from a long-term test over 12 months would be required to determine the resistance performance of heat-treated wood against rot fungi and insects. 


\section{ACKNOWLEDGMENT}

This research was funded by the research support project of the Korea Forest Service (S121315L010100).

\section{REFERENCES}

American Wood Protection Association. 2018. Book of Standards. Birmingham, Alabama, USA.

Esteves, B.M., Graça, J., Pereira, H.M. 2008. Extractive composition and summative chemical analysis of thermally treated eucalypt wood. Holzforschung 62(3): 344-351.

Esteves, B.M., and Pereira, H.M. 2009. Wood modification by heat treatment: a review. Bioresources 4(1): 370-404.

Korea Forest Service. 2016. Development of extreme energy-saving process of superheated steam treatment for concurrent drying and preservation of wood and standardization of the heat-treated wood quality In: Forest Science Technology R\&D Report.

Korean Agency for Technology and Standards. 2009. Method of determination for preservatives absorption of treated wood. KS F 2155.

Han, Y., Park, Y., Chang, Y.S., Chung, H., Eom C.D., Yeo, H. 2017. Improvement of shear strength, wood failure percentage and wet delamination of crosslaminated timber (CLT) panels made with superheated steam treated (SHST) layers of larch wood. Holzforschung 71(11): 873-879.

Homan, W.J., Jorissen A.J.M. 2004. Wood modification developments. HERON 49(4): 361-386.

Kim, O.S., Lee, D.H., Chun, W.P. 2008. Eco-Friendly drying technology using superheated steam. Korean Chemical Engineering Research 46: 258-273.

Kim, Y.S. 2016. Research trend of the heat-treatment of wood for improvement of dimensional stability and resistance to biological degradation. Journal of the Korean Wood Science and Technology 44(3): 457-476.

Militz, H. 2002. Heat treatment of wood: European processes and their background. In: International Research Group Wood Pre,Section 4-Processes, No IRG/WP 02-40241.

Park, Y., Eom, C.D., Park, J.H., Chang, Y.S., Kim, K.M., Kang, C., Yeo, H. 2012. Evaluation of physical properties of Korean pine (Pinus koraiensis Siebold \& Zucc.) lumber heat-treated by superheated steam. Journal of the Korean Wood Science and Technology 40(4): 257-267.

Park, Y., Eom, C.D., Han, Y.., Park, J.H., Chang, Y.S., Yang, S.Y., Choi, J.W., Yeo, H. 2014. Combined treatment of green pitch pine wood by heat and superheated steam and the effects on physical properties of the products. Holzforschung 68(3): 327-335.

Park, Y., Han, Y., Park, J.H., Chang, Y.S., Yang, S.Y., Chung, H., Kim, K., Yeo, H. 2015. Evaluation of physico-mechanical properties and durability of Larix kaempferi wood heat-treated by hot air. Journal of the Korean Wood Science and Technology 43(3): 334-343.

Park, Y., Park, J.H., Yang, S.Y., Chung, H., Kim, H., Han, Y., Chang, Y.S., Kim, K., Yeo, H. 2016. Evaluation of physico-mechanical properties and durability of Larix kaempferi wood heat-treated by superheated steam. Journal of the Korean Wood Science and Technology 44(5): 776-784.

Park, Y., Han, Y., Park, J.H., Chang, Y.S., Yang, S.Y., Chung, H., Yeo, H. 2017a. Evaluation of the energy efficiency of combined drying and heat treatment by superheated steam. Drying Technology 35(12): 1460-1467.

Park, Y., Jang, S.K., Park, J.H., Yang, S.Y., Chung, H., Han, Y., Chang, Y.S., Choi, I.G., Yeo, H. 2017b. Changes of major chemical components in larch wood through combined treatment of drying and 
Yonggun Park • Yeonjung Han · Jun-Ho Park • Hyunwoo Chung · Hyunbin Kim • Sang-Yun Yang • Yoon-Seong Chang $\cdot$ Hwanmyeong Yeo

heat treatment using superheated steam. Journal of Wood Science 63(6): 635-643.

Ra, J.B., Kim, K.B., Leem, K.H. 2012. Effect of heat treatment conditions on color change and termite resistance of heat-treated wood. Journal of the Korean Wood Science and Technology 40(6): 370-377.

Repellin, V., Guyonnet, R. 2005. Evaluation of heattreated wood swelling by differential scanning calorimetry in relation to chemical composition. Holzforschung 59(1): 28-34.

Sandberg, D., Haller, Peer, Navi, P. 2013. Thermohydro and thermo-hydro- mechanical wood processing: An opportunity for future environmentally friendly wood products. Wood Material Science and Engineering 8(1): 64-88.

Yoon, K.J., Eom, C.D., Park, J.H., Lee, Y.W., Choi, I.G., Lee, J.J., Yeo, H. 2008. Control of discolorration of cedar wood (Cryptomeria japonica) by heat and UV treatment. Journal of the Korean Wood Science and Technology 36(6): 33-40.

Yoon, K.J., Eom, C.D., Park, J.H., Kim, H.Y., Choi, I.G., Lee, J.J., Yeo, H. 2009. Color control and durability improvement of yellow poplar (Liriodendron tulipifera) by heat treatments. Journal of the Korean Wood Science and Technology 37(6): 487-496. 


\title{
APPENDIX
}

\author{
(Korean Version)
}

\section{2 개월 야외 내후성 시험에 의한 과열증기 열처리된 낙엽송재의 열화 평가}

요약 : 본 연구에서는 과열증기를 이용하여 열처리한 낙엽송재의 야외 내후성 시험을 통해 부후균과 해충에 대한 저항성을 평가하였다. 12 개월간 진행된 야외 내후성 시험 결과, 무처리재는 흰개미에 의한 피해가 두드러지게 나타났지만 방부목재와 과열증기 열처리재에서는 육안으로 관찰되는 피해는 발견되지 않았다. 무처리재와 방부목재는 약 $5 \%$ 의 질량 감소를 보였으며, 과열증기 열처리재는 약 $1 \%$ 의 질량 감소를 보였다. 야외 내후성 시험이 진행된 후 방부목재에 남아있는 방부약제의 함량이 야외 내후성 시험 전보다 감소한 것으로 보아 야외 내후성 시험이 진행되는 동안 방부약제가 일부 용출된 것으로 보이며, 이에 따라 방부목재의 질량 감소가 무처리재와 유사한 수준으로 나타난 것으로 생각되었다. 과열증기를 이용한 열처리는 방부약 제 주입과 같은 화학적인 처리 없이 친환경적으로 목재의 부후균과 해충에 대한 저항성을 개선시킬 수 있는 가능성이 확인되었으 며, 이를 위하여 장기적인 관찰이 추가적으로 필요할 것이라 생각된다.

\section{1. 서 론}

목재에 고온(160 $\left.260^{\circ} \mathrm{C}\right)$ 의 열을 가하면 목재의 세포벽을 구성하는 주성분(셀룰로오스, 헤미셀룰로오스 및 리그닌 등)에 열가수분해와 같은 화학적인 변화가 발생하게 되며, 이에 따라 목재의 물리-역학적 성능과 내후성능이 변화된다(Militz, 2002; Park et al., 2016). 목재 열처리는 친환경적인 방부 - 방충 처리 방법으로 2000년대 초반부터 유럽을 중심으로 다양한 연구가 수행되고 있다. 열처리된 목재는 표면 재색이 어둡게 변하고, 소수성이 증가함에 따라 치수 안정성이 개선되며, 내후성이 증가하 는 것으로 알려져 있다(Repellin and Guyonnet, 2005; Esteves et al., 2008; Yoon et al., 2008; 2009; Park et al., 2012; 2014; 2015; 2016). 이러한 물성 변화로 인해 열처리 목재는 정원용 가구, 울타리, 기둥, 목재수납장, 창문틀, 도어, 가구, 데크재, 외장벽판재 및 마루판 등 치수안정성이나 내후성이 요구되는 다양한 용도에 적용 가능한 것으로 소개되고 있다(Esteves and Fereira, 2009; Kim, 2016). 열처리에 의한 목재의 물성 변화는 열처리 온도와 시간, 그리고 열처리에 사용된 열전달 매개체의 종류에 따라 다르게 나타난다(Kim, 2016). 다양한 조건에서 열처리된 목재의 물성 변화에 대한 많은 연구들에서 소수성이 증가에 따른 치수안정 효과가 인정되고 있다(MIlitz, 2002; Homan et al., 2004; Sandberg et al., 2013; Kim, 2016). 또한, 열처리 목재는 열로 인한 목재 세포벽 주성분의 화학적 변화로 인해 목재를 가해하는 생물열화인자에 대한 저항성이 증가되는 효과가 크다고 소개되고 있다(Homan and Jorrison, 2004; Kim, 2016). 다만, 열처리 목재의 내후성은 열처리 공정, 처리조건 및 수종 등에 따라 상이하기 때문에 대상 수종에 대한 최적 조합 개발의 필요성이 매우 큰 것으로 알려져 있으며, 모든 부후균에 대해 목재 보존제를 처리한 것과 동일한 내후성을 나타내지 못하고, 토양이나 물 접촉이 되는 환경에서 내후성이 발휘되지 못하며, 특히 해충에 대한 저항성이 매우 낮기 때문에 사용환경과 용도를 고려하여 주의 깊게 사용되어야 한다는 보고가 있다 (Kim, 2016).

최근 생재를 대상으로 한 과열증기 열처리 기술에 대한 연구가 수행되고 있다(Park et al., 2012; Park et al., 2014; Park et al., 2016; Han et al., 2017; Park et al., 2017a; 2017b). 과열증기는 끓는점 이상의 온도를 갖는 증기로서 목재뿐만 아니라 식품이나 하수 슬러지 등을 건조하는 데 이용되고 있다(Kim et al., 2008). 과열증기를 이용한 생재 열처리 공정은 단일 공정을 통해 목재의 건조와 열처리가 동시에 이루어지기 때문에 에너지 손실량이 적고, 에너지 효율이 높다(Park et al., 2017a). 과열증 기를 이용한 목재 열처리 기술은 고온의 공기를 이용하여 열처리하는 관행 열기 열처리 공정에 비해 고온/고압의 수증기에 의한 열가수분해가 촉진되기 때문에 동일한 온도와 시간동안 관행 열기 열처리한 목재보다 열처리 효과가 크다(Park et al., 2014; Park et al., 2016). 이는 소수성 증가에 의한 치수안정성 증가와 종압축강도 증가 및 휨강도 감소와 같은 열처리에 의한 목재의 물성 변화가 크게 나타난다는 것을 의미한다(Park et al., 2016). 또한, 과열증기 열처리된 목재에 대한 실험실 수준에서의 부후 실험 결과 갈색부후균 및 백색부후균에 대한 저항성이 크게 증가한 것으로 보고된 바 있다(Park et al., 2014; Korea Forest Service, 2016)

본 연구에서는 과열증기 열처리된 낙엽송재를 실제로 야외에서 사용할 때의 열화 정도를 평가하기 위하여 야외 접지 내후성 시험을 12 개월간 진행하였다. 특히, 야외 접지 시험을 통해 실험실에서 진행하는 갈색부후균 및 백색부후균과 같은 부후균에 
Yonggun Park • Yeonjung Han · Jun-Ho Park • Hyunwoo Chung $\cdot$ Hyunbin Kim • Sang-Yun Yang •

Yoon-Seong Chang $\cdot$ Hwanmyeong Yeo

대한 저항성뿐만 아니라 흰개미를 포함한 다양한 충과 균에 대한 저항성을 평가하고자 하였다.

\section{2. 재료 및 방법}

\section{1. 과열증기 열처리재}

본 연구에서는 강원도 동해시 인근 산지에서 벌채한 낙엽송 생재를 산림조합중앙회 동부목재유통센터로부터 구입하여 사용 하였다. 열처리에 사용된 낙엽송 각재의 크기는 길이 $2.0 \mathrm{~m}$, 폭 $150 \mathrm{~mm}$, 두께 $50 \mathrm{~mm}$ 였다.

Figure 1은 본 연구에서 사용한 과열증기 목재 열처리 장치이다(Park et al., 2016). 장치는 반응기, 응축기, 피드탱크 및 진공펌프로 구성되어 있다. 반응기는 내부 지름 $640 \mathrm{~mm}$, 길이 $2.2 \mathrm{~m}$ 의 원통형이며, 내부 부피는 약 $0.7 \mathrm{~m}^{3}$ 이다. 반응기 내표면에 설치되어 있는 세라믹 히터를 이용하여 반응기 내부를 $400^{\circ} \mathrm{C}$ 까지 가열할 수 있도록 설계되었고, 열처리 공정 중 반응기 내부 증기의 압력을 측정할 수 있는 압력 센서 1개와 반응기 내부 증기의 온도를 측정할 수 있는 온도 센서 3 개, 그리고 목재 내부의 온도를 측정할 수 있는 온도 센서 3개가 설치되어있다. 측정되는 온도와 압력은 반응기와 연결되어 있는 컴퓨터에서 실시간으로 모니터링할 수 있다. 응축기는 목재로부터 증발되어 빠져나온 수분과 열처리에 의해 목재로부터 생성된 휘발성 유기화합물을 포집하여 응축하기 위하여 설치되었고, 피드탱크는 공정이 시작될 때 과열증기를 생성하기 위해 증류수를 투입하기 위해 설치되 었으며, 진공펌프는 공정이 시작될 때 내부 공기를 제거하기 위해 설치되었다.

과열증기 열처리 공정의 진행 순서는 다음과 같다. 먼저 반응기 내부에 낙엽송 시편을 잔적한 다음 반응기를 밀폐시키고, 내부에 과열증기 생성을 위한 증류수를 투입하였다. 이때, 투입되는 증류수의 양은 목표 온도 및 압력 조건에서 과열증기의 비체적과 반응기의 부피를 통해 결정되었다. 본 연구의 목표 조건인 $0.5 \mathrm{MPa}, 250^{\circ} \mathrm{C}$ 에서 과열증기의 비체적은 $0.47 \mathrm{~m}^{3} / \mathrm{kg}$ 이고, 반응기의 부피가 $0.7 \mathrm{~m}^{3}$ 이기 때문에 과열증기를 생성하기 위해 필요한 수분의 양은 약 $1.48 \mathrm{~kg}$ 이다. 하지만 공정초기에 반응기 내부를 빠르게 증기로 가득 차게 하도록 필요량의 2 배인 $3.0 \mathrm{~kg}$ 의 증류수를 투입하였다. 진공펌프를 이용하여 내부 공기를 제거하여 반응기 내부 압력을 $0.01 \mathrm{MPa}$ 이하가 되도록 한 다음 히터를 가동하면, 반응기 내부에 투입한 증류수가 증발되어 반응기 내부 압력이 증가한다. 반응기 내부 압력이 목표 압력에 도달하면 압력 조절 밸브를 통해 과량의 수증기가 반응기 외부로 배출되어 반응기 내부는 목표 압력을 유지한다. 반응기 내부 온도는 히터의 On/Off 시스템에 의해 목표 온도를 유지한다. 히터는 18 시간 동안 가동하였다.

열처리된 $2.0 \mathrm{~m}$ 길이의 낙엽송 각재로부터 섬유방향으로 길이 $300 \mathrm{~mm}$, 횡단방향으로 폭과 두께 $38 \mathrm{~mm}$ 인 각재를 40 개 제작하여 야외 내후성 시험에 사용하였다.

\section{2. 무처리재 및 방부처리재}

과열증기 열처리재와의 대조군으로서 무처리재(건조재)와 방부처리재가 사용되었다. 산림조합중앙회 동부목재유통센터에서 섬유방향으로 길이 $300 \mathrm{~mm}$, 횡단방향으로 폭과 두께 $38 \mathrm{~mm}$ 인 낙엽송 건조재와 H3등급의 ACQ- I(Alkaline Copper Quaternary) 낙엽송 방부목재를 각각 40개씩 구입하여 사용하였다.

\section{3. 야외 내후성 시험}

야외 내후성 시험을 위한 시험지는 전라남도 광양시 백운산에 위치한 서울대학교 남부학술림 추산시험장으로 선정하였다. 시험지는 논이나 밭에서 사용되는 제초제나 농약과 같은 화학물질이 유입될 수 없도록 논과 밭에서 떨어진 높은 언덕 지역에 조성하였다. AWPA Standard E7-15 『Standard Field Test for Evaluation of Wood Preservatives to be Used in Ground Contact (UC4A, UC4B, UC4C); Stake Test』를 참고하여 모든 시험재는 시험지 바닥에 $150 \mathrm{~mm}$ 깊이의 구덩이를 파고, 길이 방향으로 묻음으로써 시험재의 절반은 땅에 묻고, 나머지 절반은 대기에 노출되게 하였다(Figure 2). 같은 날 일괄적으로 묻은 40 개의 시험재는 10 개씩 4 그룹으로 분류하여 각각 3개월, 6 개월, 9 개월 및 12 개월 후에 회수하였다. AWPA Standard에서 는 부후된 목재를 육안으로 관찰하여 부후 정도를 평가하도록 규정하고 있으나 이는 평가자의 견해에 따라 다르게 평가될 수 있기 때문에 야외 내후성 시험 전과 후 시험재의 무게를 측정함으로써 야외 내후성 시험에 따른 시험재의 무게 변화를 정량적으로 평가하고자 하였다. 야외 내후성 시험에 따른 시험재의 질량감소율은 식 (1)에 따라 평가되었다. 이때, 시험재의 전건 무게를 측정하여 함수율에 의한 영향을 배제하였다.

\section{4. 방부목재 내 방부약제 잔류량 측정}

방부목재 내 방부약제의 잔류량을 평가하기 위해 각 기간 별로 야외 내후성 시험된 방부목 각재에 포함된 구리의 함량을 
측정하였다. 야외 내후성 시험을 하지 않은 방부목재와 3 개월, 6 개월, 9 개월 및 12 개월 간 야외 내후성 시험을 거친 방부목재, 그리고 방부처리하지 않은 무처리 낙엽송재를 $0.5 \mathrm{~mm}$ 이하로 분쇄한 다음, 서울대학교 농생명과학공동기기원 내 토양오염분석 센터에 의뢰하여 목분 내에 포함되어 있는 구리 이온의 함량을 측정하였다. 측정에는 유도 결합 플라즈마 질량분석기 (ICP(Inductively Coupled Plasma) Mass Spectrometer, Varian 820-MS, Varian, Australia)가 사용되었다.

한국산업규격의 『방부처리 목재의 약제 흡수량 측정방법』(KS F 2155)에 따라 측정된 구리 이온의 함량 $(G)$ 과 방부목재의 밀도 $(\rho)$ 를 이용하여 구리 화합물 $\left(\mathrm{CuO}, G_{o}\right)$ 의 질량을 계산하였고, 구리 화합물의 질량과 방부목재의 부피 $(V)$ 를 통해 방부약제 잔류량 $(R)$ 을 계산하였다. (식 (2), 식 (3))

\section{3. 결과 및 고찰}

\section{1. 과열증기 열처리}

Figure 3은 과열증기 열처리 중 목재의 온도 변화 및 증기의 온도와 압력 변화를 나타낸 그래프이다. 공정초기에 목재의 온도와 증기의 온도 및 압력은 빠르게 상승했다. 증기의 온도와 압력이 목표 온도 $\left(250^{\circ} \mathrm{C}\right)$ 와 목표 압력 $(0.5 \mathrm{MPa})$ 에 도달했을 때, 목재 내부의 온도는 $0.5 \mathrm{MPa}$ 에서 수증기의 포화온도 $\left(151.84^{\circ} \mathrm{C}\right)$ 에 도달했고, 약 3 시간동안 일정한 온도를 유지했다. Park 등(2014)은 과열증기 열처리 공정에서 목재의 온도가 일정하게 유지되다가 다시 증가하는 시점에서 목재가 전건되는 것으로 보고한 바 있다. 즉, 목재의 온도가 일정하게 유지되는 동안 목재 내부 수분이 모두 제거되고, 수분 제거에 이용되던 열에너지가 목질의 온도상승을 위한 에너지로 사용되면서 온도가 다시 상승하였다. 공정이 종료되는 시점에 목재의 온도는 약 $220^{\circ} \mathrm{C}$ 였다. 열처리에 의해 목재 주성분의 화학적 변화가 발생하는 온도 범위가 $160 ~ 260^{\circ} \mathrm{C}$ 인 것을 고려하면 목재는 약 10 시간 동안 열처리된 것으로 판단된다.

\section{2. 야외 내후성 시험 결과}

Figure 4 는 12 개월 야외 내후성 시험에 의한 질량 감소율 측정 결과이다. 무처리재의 질량감소율은 $3.70 \% \rightarrow 4.05 \% \rightarrow$ $4.62 \% \rightarrow 5.19 \%$ 로 초기 3 개월 만에 $3.7 \%$ 의 질량 감소가 발생한 이후, 시험 기간이 경과함에 따라 서서히 증가하는 경향을 보였고, 방부목재의 질량감소율은 $3.60 \% \rightarrow 5.09 \% \rightarrow 4.80 \% \rightarrow 4.36 \%$ 로 시험 기간과는 무관하게 측정되었으나 무처리재의 질량감소율과 유사하게 약 $4 \%$ 내외의 값을 보였다. 반면에 과열증기 열처리재의 질량감소율은 $1.10 \% \rightarrow 1.06 \% \rightarrow 0.60 \%$ $\rightarrow 1.06 \%$ 로 시험 기간과는 무관하게 전반적으로 약 $1 \%$ 내외의 값을 가졌다.

무처리재의 경우에는 Figure $5 \mathrm{~A}$ 와 같이 3개월 간 야외 내후성 시험을 진행한 목재에서도 흰개미에 의한 피해를 확인할 수 있었으며, 방부목재와 과열증기 열처리재의 경우에는 흰개미에 의한 피해가 확인되지 않았다(Figure 5B, C). 잣나무(Pinus koraiensis S. et Z.)와 로지폴소나무(Pinus contorta Dougl.) 열처리재의 흰개미에 대한 저항성이 매우 낮다고 보고된 기존 연구와는 상반된 결과가 도출되었다(Ra et al., 2012). 열처리재의 물성 변화는 수종과 처리 온도 및 처리 시간, 그리고 열처리에 사용된 열매체에 따라 그 특성이 매우 다양하게 나타나는 것으로 알려져 있다. Ra 등(2012)의 연구에서는 잣나무와 로지폴소나 무를 $170,180,200,220,230^{\circ} \mathrm{C}$ 의 온도 조건에서 $90,120,180,240,270$ 분간 열처리한 반면에, 본 연구에서는 낙엽송을 증기 온도 $250^{\circ} \mathrm{C}$ 에서 18 시간동안 열처리하였으며, 목재는 $160^{\circ} \mathrm{C}$ 이상의 고온에서 약 10 시간동안 노출되었기 때문에 기존 연구보다 고온에서 장시간 노출되었음을 알 수 있다. 또한, 과열증기 열처리 공정은 고온의 과열증기에 의해 열가수분해가 촉진되기 때문에 고온의 열기를 이용하는 관행 열기 열처리 공정보다 열처리 효과가 높은 것으로 알려져 있다(Park et al., 2016). 열처리에 의해 목재를 구성하는 주성분 중 헤미셀룰로오스가 다량 분해되며, 헤미셀룰로오스로부터 분해되어 나온 분해산물은 리그닌과 상호결합하여 거대 리그닌 고분자화된다(Esteves et al., 2008; Park et al., 2017b). 이러한 화학적 변화에 의해 $-\mathrm{OH}$ 기의 수가 감소하여 목재의 소수성이 증가하고, 상대습도에 따른 평형함수율이 감소하게 된다. 즉, 고온의 열처리에 의해 목재의 화학적 변화와 이에 따른 물성 변화가 발생하게 되고, 목재 부후균이나 흰개미와 같은 생물의 생장 조건이 변하기 때문에 과열증기를 이용하여 열처리한 목재의 내후성능이 개선되는 것이라 생각된다. 다만, 과열증기 열처리 목재의 야외내후성 시험에 대한 효과가 우수한 것으로 판단하기 위해서는 12 개월 이상의 장기적인 관찰이 필요할 것으로 생각된다.

\section{3. 방부목재 내 방부약제 잔류량 측정}

야외 내후성 시험에 따른 방부목재의 질량 감소율 측정 결과는 흰개미나 부후균에 의한 손상이 거의 없음에도 무처리재의 질량 감소율과 유사한 값으로 나타났다. 방부목재의 야외 내후성 시험을 진행하는 동안 목재 내부에 주입한 방부 약제의 외부 
용출 가능성을 평가해보고자 방부약제의 주성분 중 하나인 구리 이온의 잔류량을 측정하였다. Figure 6과 같이 야외 내후성 시험에 사용되지 않은 방부목재에서는 구리 이온의 함량이 약 $4.2 \mathrm{~g} / \mathrm{kg}$ 이었던 반면에 야외 접지 시험에 사용된 방부목재 내에서 는 $1.5 \sim 2.5 \mathrm{~g} / \mathrm{kg}$ 범위로 측정되었다. 여기에서 사용된 단위 $(\mathrm{g} / \mathrm{kg})$ 는 방부목재 $1 \mathrm{~kg}$ 에 포함되어 있는 구리 이온의 함량 $(\mathrm{g})$ 을 의미한다. 측정된 구리 이온의 함량 $(G)$ 과 방부목재의 밀도 $(\rho)$ 그리고 방부목재의 부피 $(V)$ 를 통해 계산한 방부약제 잔류량 역시 Figure 6에 제시하였다. 땅과 접촉하는 야외내후성 시험의 경우 $\mathrm{H} 4$ 등급의 방부목재가 사용되는 것이 적합하나 본 시험에서 는 $\mathrm{H} 3$ 등급의 방부목재가 사용되었다. 하지만 시험에 사용된 방부목재의 방부약제 함유량이 약 $4.9 \mathrm{~kg} / \mathrm{m}^{3}$ 로 $\mathrm{H} 4$ 등급 방부목재의 최소 약제 보유량과 유사하게 측정되었기 때문에 지접부 시험에 사용 가능할 것으로 생각되었다. 야외 내후성 시험이 진행되는 동안 사용 기간에 따른 방부약제 용출량에서 경향성이 나타나지는 않았지만, 미사용 방부목재에 비해 방부약제 잔류량이 크게 감소하였고, 이는 방부약제가 외부로 유출되었기 때문인 것으로 생각되었다. 즉, 방부목재의 질량 감소는 부후균이나 풍화에 의한 열화뿐만 아니라 방부목재 내에 주입된 방부약제의 외부 유출량도 포함된 것이라 생각된다.

\section{4. 결 론}

본 연구에서는 과열증기를 이용하여 열처리한 낙엽송재의 야외 내후성 시험을 통해 부후균과 해충에 대한 저항성을 평가하였 다. 과열증기 열처리 공정은 $0.5 \mathrm{MPa}, 250^{\circ} \mathrm{C}$ 의 과열증기 조건에서 18 시간동안 히터를 가동하는 조건을 적용하였으며, 이때 목재 내부의 최고 온도는 $220^{\circ} \mathrm{C}$ 였고, 목재의 열처리가 이루어지는 $160^{\circ} \mathrm{C}$ 이상의 온도 조건에서 목재는 약 10 시간 동안 노출되었 다. 과열증기 열처리재의 야외 내후성시험에 대한 대조군으로서 무처리재(건조재)와 ACQ-II 방부약제를 주입한 H3등급의 방부목재(방부약제 보유량 : $4.9 \mathrm{~kg} / \mathrm{m}^{3}$ )가 사용되었다.

12 개월 야외 내후성 시험 결과 과열증기 열처리재는 약 $1 \%$ 의 질량 감소를 보였으며, 육안으로 부후균이나 흰개미 등에 의한 피해는 관찰되지 않았다. 반면에 무처리재는 약 $5 \%$ 의 질량 감소를 보였으며, 흰개미에 의한 피해가 육안으로도 뚜렷하게 관찰되었다. 방부목재 또한 약 $5 \%$ 의 질량 감소를 보였으나 흰개미에 의한 피해는 관찰되지 않았다. 방부목재 내에 주입한 방부약제의 잔류량을 측정한 결과, 야외 내후성 시험이 진행되는 동안 방부목재 내에 주입된 방부약제가 일부 외부로 용출되었음 을 확인하였다. 즉, 야외 내후성 시험에 의한 방부목재의 질량 감소는 부후균이나 풍화에 의한 열화뿐만 아니라 방부약제 유출량도 포함된 것으로 생각되었다.

기존 연구에서는 열처리재의 흰개미에 대한 저항성이 매우 낮은 것으로 보고되어왔으나, 본 연구에서는 12 개월간 야외내후성 시험 결과를 통해 과열증기 열처리된 낙엽송재의 흰개미에 대한 저항성이 높게 나타났다. 이는 과열증기를 이용하여 고온에서 장시간 열처리함에 따라 열처리 효과가 크게 나타났기 때문인 것으로 생각된다. 하지만 장기적인 관찰이 요구되는 야외내후성 시험의 특성상 과열증기를 이용하여 열처리한 목재의 부후균과 해충에 대한 저항성 개선 효과는 12 개월 이상의 장기적인 시험 결과가 뒷받침되어야 할 것으로 생각된다. 